Indexed by

\title{
Scopus
}

\section{STRENGTH DEVELOPMENT OF PLAIN CONCRETE SLABS BY THE SUSTAINABILITY POTENTIAL OF LEAD-LOADED RICE HUSK (LLRH)}

Crossref

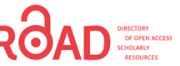

KOBSON

81Google

\section{Firas Saeed Abbas}

Mustansiriyah University, College of Engineering, Department of Environmental Engineering, Baghdad, Iraq

\author{
Wael Shahadha \\ Abdulkareem \\ Mustansiriyah University, \\ College of Engineering, \\ Department of \\ Environmental Engineering, \\ Baghdad, \\ Iraq
}

\author{
Mohammed Nsaif Abbas \\ Mustansiriyah University, \\ College of Engineering, \\ Department of \\ Environmental Engineering, \\ Baghdad, \\ Iraq
}

Key words: plain concrete slabs, flexural strength development, lead-loaded rice husk (LLRH), adsorbent waste additive, zero residue level, sustainability development doi:10.5937/jaes0-32253

Cite article:

Saeed Abbas F., Shahadha Abdulkareem W., Nsaif Abbas M. (2022) STRENGTH DEVELOPMENT OF PLAIN CONCRETE SLABS BY THE SUSTAINABILITY POTENTIAL OF LEAD-LOADED RICE HUSK (LLRH), Journal of Applied Engineering Science, 20(1), 160 - 167, DOI:10.5937/ jaes0-32253

Online aceess of full paper is available at: www.engineeringscience.rs/browse-issues 


\title{
STRENGTH DEVELOPMENT OF PLAIN CONCRETE SLABS BY THE SUSTAINABILITY POTENTIAL OF LEAD-LOADED RICE HUSK (LLRH)
}

\author{
Firas Saeed Abbas*, Wael Shahadha Abdulkareem, Mohammed Nsaif Abbas \\ Mustansiriyah University, College of Engineering, Department of Environmental Engineering, \\ Baghdad, Iraq
}

The production of environmentally friendly, sustainable plain concrete slabs is an essential requirement in this work. It is interesting to note that the ions of lead of wastewater loaded into rice husks can be used as an additive for plain concrete slabs to improve the flexural strength, as well as the workability of plain concrete slabs (or walls), which are produced by using Lead-loaded rice husk material as an additive substance in protective shields for the establishment of hospital radiology rooms. The results show that flexural strength for plain concrete slabs begins with a relative increase until it reaches breakdown. The results at age of 28 days also show that by increasing the proportion of Lead-loaded rice husk added to plain concrete slabs, the flexural strength gradually increases until it reaches onethird of the value of reference plain concrete slabs at a specific ratio, then decreases sharply until the slabs fail. These results provide a novel approach to managing toxic waste and propose an easy, simple, effective, economical, and environmentally friendly way to get rid of more than one type of waste and reach the concept of zero residue level.

Key words: plain concrete slabs, flexural strength development, lead-loaded rice husk (LLRH), adsorbent waste additive, zero residue level, sustainability development

\section{INTRODUCTION}

Concrete remains the influential primary factor in construction development, despite the participation of steel or timber, which pushes researchers to not leave concrete without developing the physical and chemical properties within the twentieth century, which correlates with installing constructions in buildings, bridges, roads, dams, and even in nuclear reactor structures. Numerous studies and frequent observations have achieved significant results concerning concrete to understand the structural behaviour and evaluation of positive and negative aspects of this vital substance (concrete). The further significance of these studies is to seek new avenues to develop this behaviour by economically workable methods and environment-friendly methods to elevate concrete from a relic of the environment [1]. Environmental concrete has significance now by directing studies towards the subject with increasing growth, which is critical in investigating the impact of environmental waste in developing the physical and chemical properties of concrete. The construction industry serves to better create an ideal environment. The growing interest in production within the industry remains in a growth state with a unique and fast way to use the waste in concrete additives admixtures [2]. Additives of environmental or agricultural residues are considered a source of green energy and have become the focus of attention of those interested in a green environment as it aims to improve the concrete while producing a clean environment [3]. One of these environmental wastes is rice husk. Rice husk may be consumed as an admixture additive to improve the properties of concrete because it is economic, sustainable, and available as a material in vast amounts around the world. It may also allow the discarding of this agricultural waste in an economical and eco-friendly way [4]. Several studies concentrate on applying various additives to evaluate the concrete admixture performance. Among these additives is rice husk. Rice husk may provide a significant advantage because a high proportion of cellulose may fill the pores in the concrete mixture which contains over $90 \%$ silica, provide excellent water resistance properties by reducing water penetration by up to $60 \%$, and reduces water heat. It also prevents the formation of cracks during concrete casting, has high resistance to chlorides, prevents the penetration of chloride ions, prevents eroding of reinforcing steel and gets rid of agricultural waste residue [5-7]. This study deals with the possibility of using rice husk residues loaded with lead element $(\mathrm{Pb})$ from contaminated water (wastewater) to form a plain concrete slab admixture. The study also looks at the properties by examination of a concrete slump test, concrete compressive strength for the cubic model, splitting tensile strength for cylindrical models and flexural strength for plain concrete slabs prepared in several concrete mixtures. The approach may count as an innovative study to strengthen concrete through the use of rice husks that absorb heavy metals (lead) from wastewater. This is a novel technique that is premiering in this study for the manufacture of an environmental concrete additive that uses agricultural remnant waste to absorb the metals from wastewater in a plain concrete slab to investigate the flexural strength. 


\section{RESEARCH MATERIALS}

\section{Cement}

To match the Iraqi specifications (Number 5 of 2019) [8] shown in Table (1) and Table (2), various laboratory tests (chemical and physical, respectively) are performed for the cement.

Table 1: Results of chemical tests (cement)

\begin{tabular}{|c|c|c|}
\hline $\begin{array}{c}\text { Chemical } \\
\text { compound }\end{array}$ & (cement) & $\begin{array}{c}\text { IRAQ-standard } \\
(5) / 2019\end{array}$ \\
\hline $\mathrm{Ca}$ O & 61.36 & 60 to 69 \\
\hline $\mathrm{Si}$ O2 & 22 & 18 to 24 \\
\hline $\mathrm{Fe} 2$ O3 & 3.8 & 2 to 4 \\
\hline $\mathrm{Na} 2$ O & 0.8 & \\
\hline $\mathrm{A} 2$ 2 O3 & 5.81 & 4 to 8 \\
\hline $\mathrm{Mg} \mathrm{O}$ & 2.7 & 2 to 5 \\
\hline $\mathrm{Ca}$ O F & 1.62 & 0 to 2 \\
\hline $\mathrm{S}$ O 3 & 0.65 & 0.3 to 2.7 \\
\hline K2 O & 0.75 & \\
\hline "L-S-F." & 0.76 & 0.66 to 1.02 \\
\hline "I.- R." & 0.51 & \\
\hline "L- O -I." & 0.45 & 0.1 to 0.5 \\
\hline (C2S) & 22.8 & 10 to 25 \\
\hline (C3S) & 56 & 45 to 65 \\
\hline (C3A) & 8.63 & 7 to 12 \\
\hline (C4AF) & 12.2 & 11 to 15 \\
\hline
\end{tabular}

\section{Fine aggregates}

A sandy classification is equivalent to the Iraqi standard (Number 45 of 1984) [9], as seen in Table (3). This work employs greenish sand, specific gravity (2.58), softness (2.642), and sulphate salts ( 0.11 percent).

Table 3: Aggregate (fine) classification

\begin{tabular}{|c|c|c|}
\hline Sieve & $\begin{array}{c}\text { Passing } \\
\%\end{array}$ & $\begin{array}{c}\text { IRAQI - standard } \\
(45) / 1985(2)\end{array}$ \\
\hline 10 & 100 & 100 \\
\hline 4.75 & 96 & 90 to 100 \\
\hline 2.36 & 87 & 75 to 100 \\
\hline 1.18 & 68 & 55 to 90 \\
\hline 0.6 & 47 & 35 to 59 \\
\hline 0.3 & 22 & 8 to 30 \\
\hline 0.15 & 2 & 0 to 10 \\
\hline $\begin{array}{c}\text { Fine materials that can } \\
\text { pass through sieve } \\
\text { Number (200) }\end{array}$ & 0 & $<5 \%$ \\
\hline
\end{tabular}

Table 2: Results of physical examination of (cement)

\begin{tabular}{|c|c|c|c|}
\hline 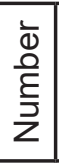 & Examination title & (cement) & $\begin{array}{l}\text { IRAQ stadard } \\
\text { (5) / } 2019\end{array}$ \\
\hline 1 & Specific-gravity & [3.2 ] & \\
\hline 2 & $\begin{array}{c}\text { (Standard } \\
\text { consistence) \% }\end{array}$ & 31 & 26 to $33 \%$ \\
\hline 3 & (Soundness) \% & 0.35 & $\begin{array}{c}\text { Not more } \\
\text { than } 0.8\end{array}$ \\
\hline 4 & Fineness $\left(\mathrm{cm}^{2} / \mathrm{gm}\right)$ & 3341 & $\begin{array}{c}\text { Not less than } \\
2,300\end{array}$ \\
\hline 5 & "setting-time-initial" & 115 & $\begin{array}{c}\text { Not less than } \\
60 \text { Min }\end{array}$ \\
\hline & "setting-time-final" & 370 & $\begin{array}{c}\text { Not more } \\
\text { than } 600 \text { Min }\end{array}$ \\
\hline 6 & \multicolumn{3}{|c|}{ "Compressive-strength" } \\
\hline & Age. : three-days. & 17.4 & $\begin{array}{c}\text { Not less than } \\
15 \mathrm{~N} / \mathrm{mm}^{2} \\
\end{array}$ \\
\hline & Age. : seven-days. & 25.1 & $\begin{array}{c}\text { Not less than } \\
23 \mathrm{~N} / \mathrm{mm}^{2}\end{array}$ \\
\hline 7 & \multicolumn{3}{|c|}{ "Flexural - strength" } \\
\hline & Age. : three-days. & $\begin{array}{c}8.1 \\
\left(\mathrm{~N} / \mathrm{mm}^{2}\right) \\
\end{array}$ & \\
\hline & Age. : seven-days. & $11\left(\mathrm{~N} / \mathrm{mm}^{2}\right)$ & \\
\hline
\end{tabular}

\section{Coarse aggregates}

Specific gravity (2.62), sulphate salts (0.048 percent), and Nominal size (5 to $20 \mathrm{~mm}$ ) is used as coarse aggregate. It is equivalent to the standard of Iraqi (Number 45 of 1984) [9]. Table 4 describes the aggregate (coarse) scales

Table 4: Grading for coarse aggregates

\begin{tabular}{|c|c|c|}
\hline Sieve & $\begin{array}{c}\text { Percentage } \\
\text { passing }\end{array}$ & $\begin{array}{c}\text { IRAQ - standard } \\
\text { (45) / 1985 (2) }\end{array}$ \\
\hline 37.5 & 100 & 100 \\
\hline 20 & 98 & 95 to 100 \\
\hline 10 & 48 & 30 to 60 \\
\hline 5 & 3 & 0 to 10 \\
\hline $\begin{array}{c}\text { Materials that can } \\
\text { pass through sieve } \\
\text { Number (75) }\end{array}$ & 0 & $<3 \%$ \\
\hline
\end{tabular}

\section{Lead-loaded rice husk}

Rice husks from Iraqi rice fields can be used by an utterly innovative process when loading the rice husks with lead (as an additive to concrete) using the adsorption technique, which is applied to aqueous-solutions under 
different conditions. The lead element $(\mathrm{Pb})$ is loaded in the rice husks in a range between (9.51 to 24.06$) \mathrm{mg} / \mathrm{g}$. Rice husks are loaded with lead $(\mathrm{Pb})(10 \mathrm{mg} / \mathrm{g})$ from aqueous solutions, dried for 24 hours, then extracted and passed through a 200-micron sieve and collected in unique moisture-resistant bags for later use in order to prepare the concrete admixture. Table (5) and Figure (1) show the chemical composition and X-ray analysis of the rice husks used in this experiment.

Table 5: Specification of (rice husks)

\begin{tabular}{|c|c|c|}
\hline Number & Chemical compound & weight $\%$ \\
\hline 1 & $\mathrm{~K} 2 \mathrm{O}$ & 2.65 \\
\hline 2 & Si O2 & 90 \\
\hline 3 & $\mathrm{Fe} 2 \mathrm{O} 3$ & 0.05 \\
\hline 4 & $\mathrm{CaO}$ & 0.63 \\
\hline 5 & $\mathrm{Al} 2 \mathrm{O} 3$ & 0.15 \\
\hline 6 & $(\mathrm{Mg} \mathrm{O})$ & 0.28 \\
\hline 7 & $\mathrm{Na} 2 \mathrm{O}$ & 0.08 \\
\hline 8 & $\mathrm{P} 2 \mathrm{O} 4$ & 0.71 \\
\hline 9 & $\mathrm{Ti} \mathrm{O} 2$ & 0.013 \\
\hline 10 & "L.-O.-I." & 4.70 \\
\hline 11 & $\begin{array}{l}\text { The amount of lead loaded } \\
\text { on the husk after the end } \\
\text { of the adsorption process }\end{array}$ & $\begin{array}{l}\text { (10 mg lead)/ } \\
\text { (1 g rice husk) }\end{array}$ \\
\hline
\end{tabular}

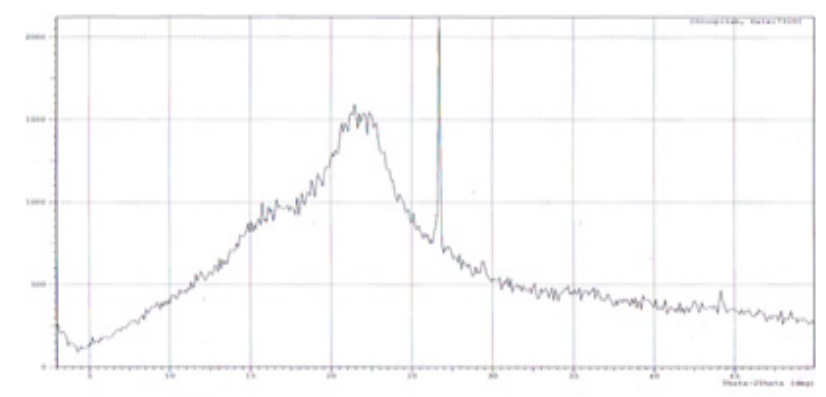

Figure 1: X-ray analysis of lead-free rice husks [10]

\section{Water}

For mixing, the concrete models are mixed with tap water.

\section{Research method}

In order to develop the properties of the plain concrete slab used in the current investigation, a water-cement ratio equal to 0.45 plus Lead-loaded rice husk (LLRH) with a weight ranging from $0.5 \%$ to $3 \%$ of the mixture is used. Moreover, the mixture-proportions (cement: sand: coarse aggregate) of 1: 2: 4 is applied. Table (6) shows the details of the concrete mixes used in the study. First, the fine and coarse aggregates are washed with water to eliminate any retained dust or impurities and then left until dry in the sun for 24 hours. After making sure that the aggregates are dry, the cement, fine aggregates, and the leaded rice husks are mixed as a dry mixture. Then the mixture is placed in a concrete mixer (capacity $25 \mathrm{~kg}$ ) and two-thirds of the coarse aggregate weight is mixed with the blended materials to the acceptable homogeneity level. The remaining water and gravel is added to the mix, and the mixture is continued to mix until it becomes homogeneous.

\section{Table 6: Concrete-mixture content}

\begin{tabular}{|c|c|c|c|c|c|}
\hline \multirow{2}{*}{ 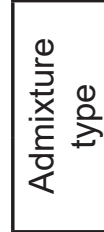 } & $\begin{array}{c}\text { Lead } \\
\text { loaded } \\
\text { rice husk }\end{array}$ & cement & sand & gravel & \multirow[t]{2}{*}{ (W./C.) } \\
\hline & $\begin{array}{l}(\mathrm{kg}) / \\
\left(\mathrm{m}^{3}\right)\end{array}$ & $\begin{array}{l}(\mathrm{kg}) / \\
\left(\mathrm{m}^{3}\right)\end{array}$ & $\begin{array}{l}(\mathrm{kg}) / \\
\left(\mathrm{m}^{3}\right)\end{array}$ & $\begin{array}{l}(\mathrm{kg}) / \\
\left(\mathrm{m}^{3}\right)\end{array}$ & \\
\hline 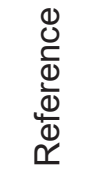 & 0 & 300 & 600 & 1200 & 0.45 \\
\hline 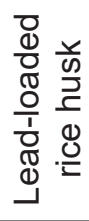 & $\begin{array}{c}(0.5 \text { to } 3) \\
\%\end{array}$ & 300 & 600 & 1200 & 0.45 \\
\hline
\end{tabular}

Following the British standard BS 1881: Part-113, 2011 [11], a cubic-shaped iron is used as a model for a compressive strength test. The cubic steel moulds are filled with concrete mixture in three mechanically hammered layers using a vibrator for 10 to 15 seconds to obtain homogeneous concrete. A cylindrical mould size of 15 $x 30 \mathrm{~cm}$ and ASTM C.496 [12] is applied for the splitting tensile strength test. The cylindrical moulds are filled with the concrete mix on three layers and then hand-hammered using the iron rod for 25 strikes per layer to get a homogeneous concrete mix. Finally, a concrete slab template, square-shaped steel $(400 \times 400 \times 50) \mathrm{mm}$, is used to examine the flexural strength for the plain concrete slabs. When the casting process is completed for the cubes, cylinders, and slabs models, the moulds are covered with nylon for 24 hours. The specimens are then removed from the moulds and placed in specially equipped basins filled with tap water at a temperature of 20 to $25^{\circ} \mathrm{C}$ for maturation. The different models are left in the maturation basins until the test days on day 7 and day 28 (age).

\section{TESTING METHODS}

\section{Slump test}

The test consists of twenty-one samples of concrete mixtures according to BS EN 12350-2-2019 [13], for which 
the measurement rate depends on three test attempts for seven groups by using a cone to perform a test called an "Abrams cone" made of metal (2 mm thickness) with a $200 \mathrm{~mm}$ bottom diameter, $100 \mathrm{~mm}$ upper diameter, 305 $\mathrm{mm}$ height, and an inner surface as smooth as possible. The cone is filled with concrete with a three layer strike by a metal rod of length $60 \mathrm{~cm}$ and a diameter of $16 \mathrm{~mm}$ with a circular edge strike by 25 strikes for each layer, provided that the stick reaches the layer underneath it till touching the bottom. The top layer is cleaned from any residual concrete that may leak between the cone and the metal base. A concrete slump measures the difference between cone height and the highest point in the centre of the concrete sample after subsidence.

\section{Compressive strength test}

Twenty-one cubic models are considered in the concrete compressive-strength test to investigate the influence of Lead-loaded rice husks as an additive to concrete hardness, which is used later in the concrete slabs models. Seven groups of concrete mixture are adopted and each one contains three cube models of $(150 \times 150 \times 150)$ $\mathrm{mm}$ as a test model. Water curing is applied for seven days and 28 days at $20^{\circ} \mathrm{C}$, according to BS.EN. 12390"3."-2019 [14]. The test of compressive-strength is carried out for concrete cubes and is performed at seven days and 28 days by the Wekob (2500 kN) method at a speed of $(15 \mathrm{MN} / \mathrm{m} 2 / \mathrm{min})$ up to the failure of the cube model. Three cubic models are used for each mixture for both ages (seven days and 28 days) to calculate the compressive strength. The compressive strength is calculated as an average rate for the resistance of three concrete cubes.

\section{Fresh concrete density test}

The fresh density of the concrete is determined according to ASTM C.138 [15]. Table (9) shows the fresh concrete density test results for the reference mix and additive mixtures.

\section{Dry concrete density test}

The dry density of the concrete is determined according to ASTM C.567 [16]. A concrete drum is installed after casting and maturation for at least 24 hours and not over 32 hours in a $110{ }^{\circ} \mathrm{C}\left( \pm 5^{\circ} \mathrm{C}\right)$ thermal oven for 72 hours or until arrival at a constant weight after cooling the cylinder at room temperature. The weight and size of the dry density of the concrete is recorded as shown in Table (9).

\section{Splitting tensile strength test}

TThe tensile strength of the concrete is significant because it significantly affects the dimensions of any cracks in the concrete, which is very low in value, about 10 to $15 \%$ of the compressive strength. According to ASTM C.496 [12], a split cylinder test typically operates at the tensile strength, which is carried out using cylindrical concrete models for the reference concrete mixture of other concrete mixtures. The concrete cylinder is poured in dimensions of $(15 \times 30) \mathrm{cm}$ and allowed to cure for 28 days. It is examined by a Wekob test machine under the influence of compressive forces in opposite directions and two influencing diameters through a plywood loading plate with two axial lines. The plywood backing of the applied load extends across a tiny width, which suffices to eliminate any unacceptable pressure intensity and adjust any surface irregularity. This compression load generates a steady crosswise pressure for the columnar diameter, and thus the tensile failure is along the vertical diameter for the cross-section.

\section{Concrete slab flexural-strength test}

The standard test starts by placing a plain concrete slab then Lead-loaded rice husk concrete slabs sequentially in the centre of the compression testing machine. The distance between the two supports is about two-thirds of the plain concrete slab length, while the part extending outside the supports is about one-sixth of the plain concrete slab length from each side as shown in Figure (2), and loading increases until the plain concrete slab is broken. The present work involves 21 plain concrete slabs, which are divided into seven groups. Each group contains three concrete slab models with dimensions $(400 \times 400 \times 50) \mathrm{mm}$ for each concrete slab mixture by ASTM C.293 [17].

Flexura Strength (modulus of rupture) $(\mathrm{fb})=\frac{3 F L}{2 B h^{2}}$

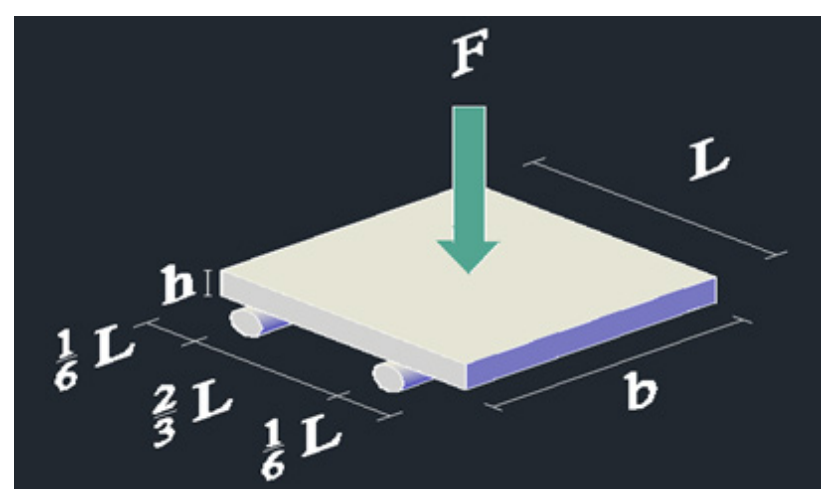

Figure 2: Plain concrete slab and concrete slab testing details

\section{RESULTS AND DISCUSSION}

\section{The concrete slump - experiment}

Table (7) and Figure (3) present the results of the slump test for the reference concrete mix and additive mixtures. The amount of slump decreases with the increase in the proportion of Lead-loaded rice husks added to the concrete mix for the result shown in Table 7 and Figure 3. This decrease may be because the addition of rice husks as fine granulated grains (dust) may increase the surface area of the aggregate.Therefore, there is a need to increase the ratio of water/cement to increase the wetting of the aggregate surface area because of the absorption 
of water by the amount of added rice husks. In contrast, the water/cement ratio (W./C.) is constant $(0.45)$, so the amount of slump may decrease according to adding wastes such as rice husk [18].

Table 7: Concrete slump test results

\begin{tabular}{|c|c|c|c|}
\hline 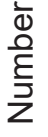 & $\begin{array}{c}\text { Concrete admixture } \\
\text { type }\end{array}$ & $\begin{array}{l}\text { Lead-loaded rice } \\
\text { husk (gm) }\end{array}$ & $\begin{array}{l}\text { Slump } \\
(\mathrm{mm})\end{array}$ \\
\hline 1 & Reference & 0 & 92 \\
\hline 2 & $\begin{array}{c}\text { Lead-loaded rice } \\
\text { husk }\end{array}$ & $0.5 \%=35.45$ & 86 \\
\hline 3 & $\begin{array}{c}\text { Lead-loaded rice } \\
\text { husk }\end{array}$ & $1.0 \%=70.90$ & 72 \\
\hline 4 & $\begin{array}{c}\text { Lead-loaded rice } \\
\text { husk }\end{array}$ & $1.5 \%=106.35$ & 66 \\
\hline 5 & $\begin{array}{l}\text { Lead-loaded rice } \\
\text { husk }\end{array}$ & $2.0 \%=141.80$ & 58 \\
\hline 6 & $\begin{array}{c}\text { Lead-loaded rice } \\
\text { husk }\end{array}$ & $2.5 \%=177.25$ & 38 \\
\hline 7 & $\begin{array}{c}\text { Lead-loaded rice } \\
\text { husk }\end{array}$ & $3.0 \%=212.70$ & 0 \\
\hline
\end{tabular}

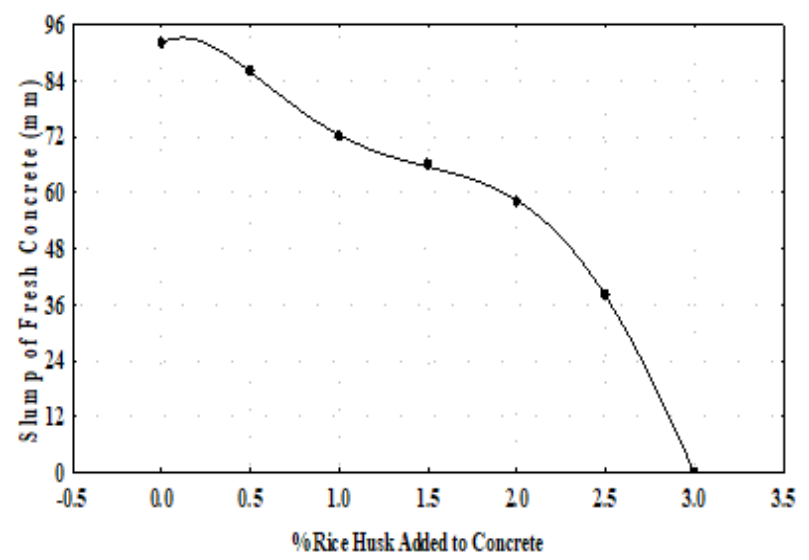

Figure 3: The addition effect of lead-loaded rice husks on the concrete slump

\section{Compressive strength test}

Adding any fine grains in a limited percentage, including ground rice husks added (without $\mathrm{Pb}$ loading) to concrete, enhances the compressive strength as a simple elementary value because adding such material requires an increase in the amount of added water and thus leads to a reduction in compressive strength. However, the results from this study show the reverse behaviour in which the compressive resistance for the concrete cubes increases at seven days of age and at 28 days of age compared to the references concrete cubes. The percentage of Lead-loaded rice husk can be increased up to $2 \%$. After that, the resistance decreases until the cubic models fail at $3 \%$ value to the Lead-loaded rice husk as shown in Table (8) and Figure (4) for the reference concrete mixture and Lead-loaded rice husk concrete mixtures.

Table 8: Compressive strength test result

\begin{tabular}{|c|c|c|c|c|}
\hline \multirow{2}{*}{$\begin{array}{l}\text { बे } \\
\text { है } \\
\text { है }\end{array}$} & \multirow{2}{*}{$\begin{array}{l}\text { Concrete } \\
\text { admixture } \\
\text { type }\end{array}$} & \multirow{2}{*}{$\begin{array}{l}\text { Lead-loaded rice } \\
\text { husk, }(\mathrm{gm})\end{array}$} & \multicolumn{2}{|c|}{$\begin{array}{c}\text { Compressive } \\
\text { strength } \\
\left(\mathrm{N} / \mathrm{mm}^{2}\right)\end{array}$} \\
\hline & & & 7 days & $\begin{array}{c}28 \\
\text { days }\end{array}$ \\
\hline 1 & Reference & 0 & 25.77 & 31.68 \\
\hline 2 & $\begin{array}{l}\text { Lead-loaded } \\
\text { rice husk }\end{array}$ & $0.5 \%=35.45$ & 34.85 & 42.78 \\
\hline 3 & $\begin{array}{l}\text { Lead-loaded } \\
\text { rice husk }\end{array}$ & $1.0 \%=70.90$ & 40.44 & 49.79 \\
\hline 4 & $\begin{array}{l}\text { Lead-loaded } \\
\text { rice husk }\end{array}$ & $1.5 \%=106.35$ & 49.2 & 60.48 \\
\hline 5 & $\begin{array}{l}\text { Lead-loaded } \\
\text { rice husk }\end{array}$ & $2.0 \%=141.80$ & 54.86 & 67.39 \\
\hline 6 & $\begin{array}{l}\text { Lead-loaded } \\
\text { rice husk }\end{array}$ & $2.5 \%=177.25$ & 28.75 & 35.32 \\
\hline 7 & $\begin{array}{l}\text { Lead-loaded } \\
\text { rice husk }\end{array}$ & $3.0 \%=212.70$ & - & - \\
\hline
\end{tabular}

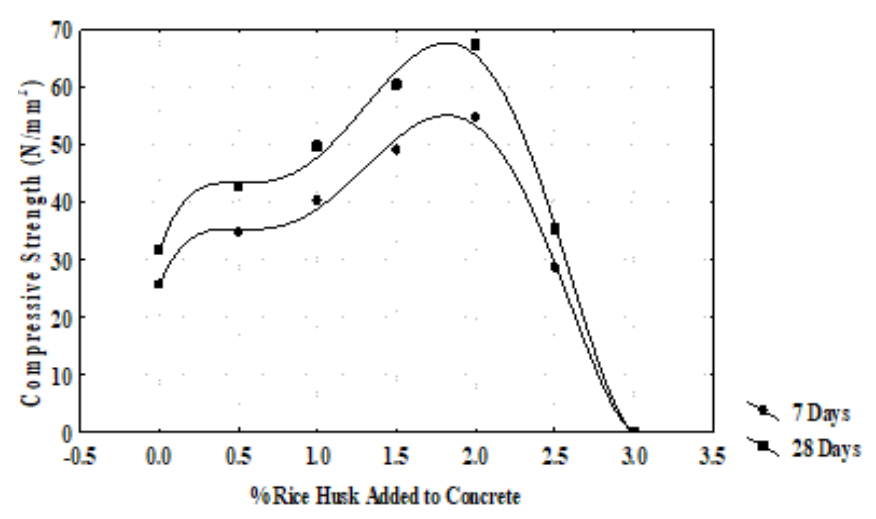

Figure 4: Effect of addition of loaded-lead rice husks on concrete compressive strength

This behaviour may also be because the grains of the rice husks may have overlapped with and fall between the coarse and fine aggregate granules that produce the largest gradation. So this leads to reduce the gaps in the concrete structure, thus enhancing the texture of the concrete mixture, which is usually full of pores that act to weakening the concrete structure. Hence the use of finegrained rice husk may start to fill and reduce these gaps, thus increasing the homogeneity of the concrete mixture and therefore increasing its resistance. Moreover, the increase in the hardness of the Lead-loaded rice husk concrete may increase the adhesion strength between the grains of the Lead-loaded rice husk and concrete cement particles, which depends on the general properties resulting from the composition content of rice husks This may be noted in Table (1) and Table (5) for the rice husk chemical composition which closely relates to the 
chemical composition of the cement. The other explanation for this result may refer to the Lead $(\mathrm{Pb})$, which is considered a high-density element that leads to a rise in concrete durability because of its penetration into the concrete admixture.

\section{Fresh and dry concrete density tests}

The dry density and fresh density for the reference concrete mixture and additive mixtures are presented in Table (9) and Figure (5) and show that the fresh and dry concrete density increases when the lead-loaded rice husk content is increased. That may be because the Lead-loaded rice husks add very fine granules to the concrete mixture and that the amount is not over $3 \%$. This represents a mass added to the concrete mass, which means increasing the density within the fixed volume. Also, the Lead $(\mathrm{Pb})$ element adsorbed and carried by the rice husks is considered as a high-density element, so the greater the amount of added rice husks means the higher the amount of lead element loaded, which results in greater weight added, so the density of the concrete increases by a maximum of $4.18 \%$ for the dry density and $4.94 \%$ for the fresh density.

Table 9: Results of the test of fresh and dry concrete density for the concrete mixtures

\begin{tabular}{|c|c|c|c|c|}
\hline \multirow{2}{*}{$\begin{array}{c}\bar{\Phi} \\
\bar{\Xi}\end{array}$} & $\begin{array}{c}\text { Concrete } \\
\text { Admixture } \\
\text { type }\end{array}$ & $\begin{array}{c}\text { Lead-loaded rice } \\
\text { husk (gm) }\end{array}$ & \multicolumn{2}{|c|}{$\begin{array}{c}\text { Concrete } \\
\text { admixture } \\
\text { density }\left(\mathrm{gmcm}^{3}\right)\end{array}$} \\
\cline { 4 - 5 } & & 0 & 2.205 & 2.105 \\
\hline 1 & Reference & Fresh & Dry \\
\hline 2 & $\begin{array}{c}\text { Lead-loaded } \\
\text { rice husk }\end{array}$ & $0.5 \%=35.45$ & 2.246 & 2.117 \\
\hline 3 & $\begin{array}{c}\text { Lead-loaded } \\
\text { rice husk }\end{array}$ & $1.0 \%=70.90$ & 2.256 & 2.131 \\
\hline 4 & $\begin{array}{c}\text { Lead-loaded } \\
\text { rice husk }\end{array}$ & $1.5 \%=106.35$ & 2.267 & 2.152 \\
\hline 5 & $\begin{array}{c}\text { Lead-loaded } \\
\text { rice husk }\end{array}$ & $2.0 \%=141.80$ & 2.278 & 2.168 \\
\hline 6 & $\begin{array}{c}\text { Lead-loaded } \\
\text { rice husk }\end{array}$ & $2.5 \%=177.25$ & 2.292 & 2.183 \\
\hline 7 & $\begin{array}{c}\text { Lead-loaded } \\
\text { rice husk }\end{array}$ & $3.0 \%=212.70$ & 2.314 & 2.193 \\
\hline
\end{tabular}

\section{Splitting tensile strength test}

The test outcomes for the total mixtures of the concrete are presented in Table (10) and Figure (6) which shows the splitting tensile strength rising as the percentage of Lead-loaded rice husk (LLRH) increases up to $2 \%$ of the

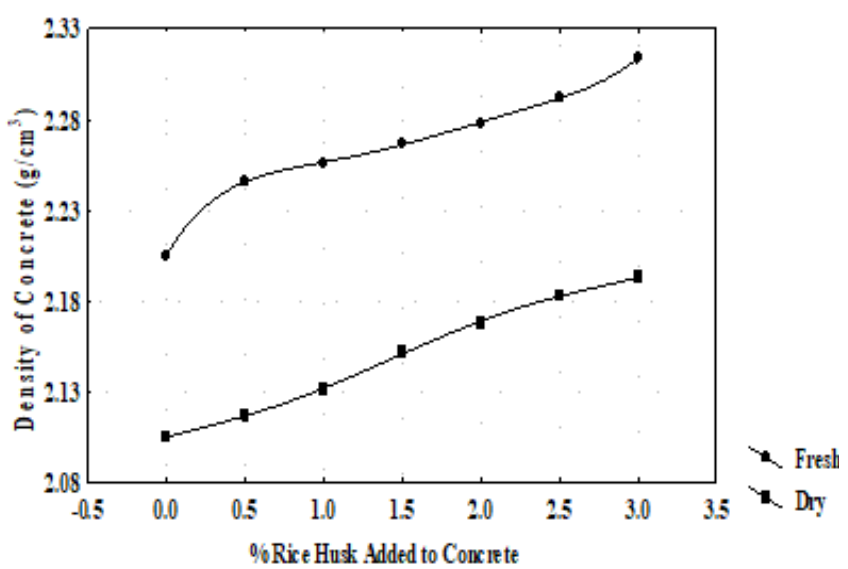

Figure 5: Effect of the addition of lead-loaded rice husk on the density of fresh and dry concrete

concrete mixtures and then decreases until the models fail at $3 \%$. As the rice husks are considered to be a highly effective pozzolanic material, their use in varying proportions often leads to exhaustion of calcium-hydroxide, which is available in the cement mixture and improves the concrete porous media [19]. This may also refer to the adsorbed Lead $(\mathrm{Pb})$ in rice husk, which counts as a high-density element that may increase the compressive strength for the Lead-loaded rice husk concrete mixtures.

Table 10: Splitting tensile strength test result

\begin{tabular}{|c|c|c|c|}
\hline $\begin{array}{c}\overline{\mathbf{\Phi}} \\
\bar{\Xi} \\
\bar{z}\end{array}$ & $\begin{array}{c}\text { Concrete } \\
\text { admixture } \\
\text { type }\end{array}$ & $\begin{array}{c}\text { Lead-loaded } \\
\text { rice husk (gm) }\end{array}$ & $\begin{array}{c}\text { Splitting tensile } \\
\text { strength (N/mm2) }\end{array}$ \\
\hline 1 & Reference & 0 & 5.75 \\
\hline 2 & $\begin{array}{c}\text { Lead-loaded } \\
\text { rice husk }\end{array}$ & $0.5 \%=35.45$ & 6.25 \\
\hline 3 & $\begin{array}{c}\text { Lead-loaded } \\
\text { rice husk }\end{array}$ & $1.0 \%=70.90$ & 6.83 \\
\hline 4 & $\begin{array}{c}\text { Lead-loaded } \\
\text { rice husk }\end{array}$ & $1.5 \%=106.35$ & 7.21 \\
\hline 5 & $\begin{array}{c}\text { Lead-loaded } \\
\text { rice husk }\end{array}$ & $2.0 \%=141.80$ & 7.64 \\
\hline 6 & $\begin{array}{c}\text { Lead-loaded } \\
\text { rice husk }\end{array}$ & $2.5 \%=177.25$ & 4.15 \\
\hline 7 & $\begin{array}{c}\text { Lead-loaded } \\
\text { rice husk }\end{array}$ & $3.0 \%=212.70$ & - \\
\hline
\end{tabular}




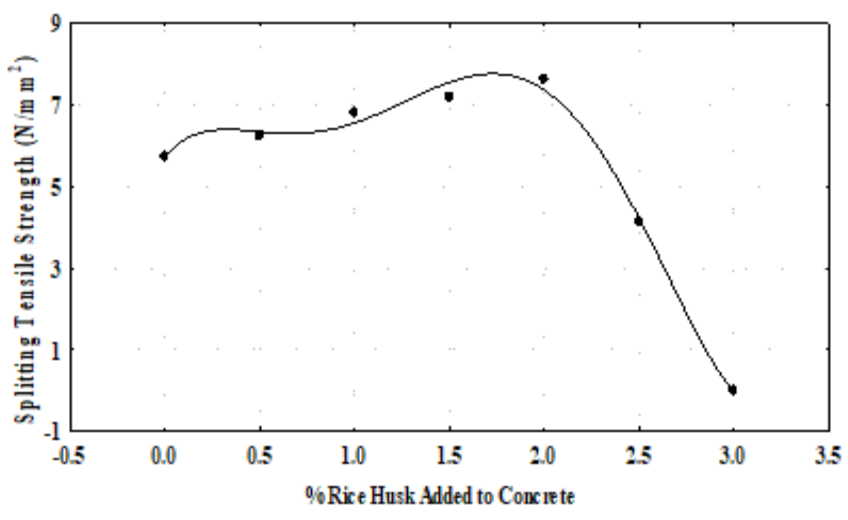

Figure 6: Effect of the addition of lead-loaded rice husk on the split tensile strength of concrete cylindrical models

\section{Concrete slab flexural-strength}

The test outcomes present the flexural strength for the plain concrete slab and lead-loaded rice husk concrete slabs in Table 11 and Figure 7, explaining that the flexural strength increases when the ratio of Lead-loaded rice husks to concrete slab mixture increases from 0.5 $\%$ to $2.0 \%$. So rice husks, in a very fine granular form, may reduce and fill the gaps and pores in the concrete mixtures. The lead $(\mathrm{Pb})$ element may also increase the density of the concrete mixture and thus increase the flexural strength of the concrete slabs with Lead-loaded rice husks by increasing the ratio of added Lead-loaded rice husks.

Table 11: Plain concrete slab and concrete slabs flexural strength results

\begin{tabular}{|c|c|c|c|c|}
\hline \multirow{2}{*}{\begin{tabular}{|l}
$\overline{\mathbf{d}}$ \\
$\overline{\mathrm{z}}$ \\
$\bar{\Sigma}$
\end{tabular}} & \multirow{2}{*}{$\begin{array}{l}\text { Concrete } \\
\text { slabs types }\end{array}$} & \multirow{2}{*}{$\begin{array}{l}\text { Lead-loaded } \\
\text { rice husk (gm) }\end{array}$} & \multicolumn{2}{|c|}{$\begin{array}{l}\text { Flexural-strength } \\
\text { "N/mm" }\end{array}$} \\
\hline & & & $\begin{array}{l}\text { Age }= \\
7 \text { days }\end{array}$ & $\begin{array}{c}\text { Age }= \\
28 \text { days }\end{array}$ \\
\hline 1 & Reference & 0 & 2.67 & 4.55 \\
\hline 2 & \begin{tabular}{|c|}
$\begin{array}{c}\text { Lead-loaded } \\
\text { rice husk }\end{array}$ \\
\end{tabular} & $0.5 \%=35.45$ & 3.16 & 4.93 \\
\hline 3 & $\begin{array}{l}\text { Lead-loaded } \\
\text { rice husk }\end{array}$ & $1.0 \%=70.90$ & 3.54 & 5.39 \\
\hline 4 & $\begin{array}{c}\text { Lead-loaded } \\
\text { rice husk }\end{array}$ & $1.5 \%=106.35$ & 3.61 & 5.68 \\
\hline 5 & $\begin{array}{l}\text { Lead-loaded } \\
\text { rice husk }\end{array}$ & $2.0 \%=141.80$ & 3.75 & 6.24 \\
\hline 6 & $\begin{array}{l}\text { Lead-loaded } \\
\text { rice husk }\end{array}$ & $2.5 \%=177.25$ & 2.05 & 3.27 \\
\hline 7 & $\begin{array}{l}\text { Lead-loaded } \\
\text { rice husk }\end{array}$ & $3.0 \%=212.70$ & - & - \\
\hline
\end{tabular}

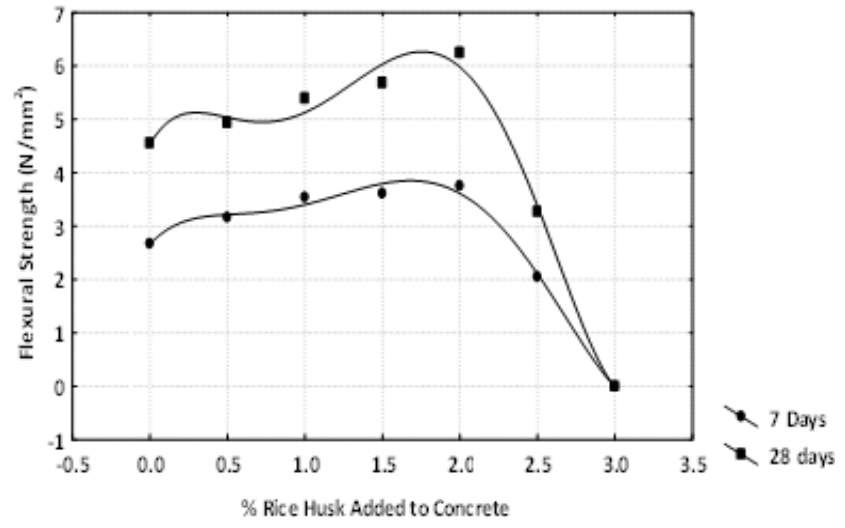

Figure 7: Effect of the addition of lead-loaded rice husk on the flexural strength for plain concrete slabs and additive concrete slabs

\section{CONCLUSIONS}

1. Lead-loaded rice husk (LLRH) indicated effectiveness in the plain concrete slab, which may be taken as an additional reinforcement material for plain concrete slabs.

2. The plain concrete slabs with Lead-loaded rice husks, show the ability to develop bending resistance.

3. Lead-loaded rice husks showed a high potential for improving the resistance properties of the concrete mixture.

4. The possibility arises of producing high-performance concrete by producing high compressive strength concrete.

5. An apparent improvement in testing the tensile strength of the concrete mixture with Lead-loaded rice husks may increase its use in the concrete tensile area.

6. The concrete admixture with lead-loaded rice husks may be applied as a concrete finish and in decoration work due to reducing the percentage of the slump.

7. Lead-loaded rice husks in the concrete mix may increase the wet and dry density of the concrete mix.

8. The possibility of adding Lead-loaded rice husks to the concrete mixture and plain concrete slabs opens the door to studying the possibility of using it in the walls and slabs of X-ray rooms and in any special construction that needs to reduce the harmful X-ray emissions emanating from them.

\section{ACKNOWLEDGMENTS}

The author(s) would like to thank MUSTANSIRIYAH UNIVERSITY (www.uomustansiriyah.edu.iq) Baghdad / Iraq for their support of the present work 


\section{REFERENCES}

1. Akhtar, A., \& Sarmah, A. K. (2018). Novel biochar-concrete composites: Manufacturing, characterization and evaluation of the mechanical properties. Science of the total environment, 616, 408-416, DOI: 10.1016/j.scitotenv.2017.10.319.

2. Khalil, A. A., Tawfik, A., Hegazy, A. A., \& El-Shahat, M. F. (2014). Effect of some waste additives on the physical and mechanical properties of gypsum plaster composites. Construction and building materials, 68, 580-586, DOI: 10.1016/j.conbuildmat.2014.06.081.

3. Nagrockienè, D., Girskas, G., \& Skripkiūnas, G. (2017). Properties of concrete modified with mineral additives. Construction and Building Materials, 135, 37-42. , DOI: 10.1016/j.conbuildmat.2016.12.215.

4. Le, H. T., \& Ludwig, H. M. (2016). Effect of Rice Husk ash and other mineral admixtures on properties of self-compacting high performance concrete. Materials \& Design, 89, 156-166, DOI:, 10.1016/j.matdes.2015.09.120.

5. Bheel, N., Abro, A. W., Shar, I. A., Dayo, A. A., Shaikh, S., \& Shaikh, Z. H. (2019). Use of rice husk ash as cementitious material in concrete. Engineering, Technology \& Applied Science Research, vol. 9, no. 3, 4209-4212, DOI: 10.48084/etasr.2746.

6. Bheel, N., Kumar, A., Shahzaib, J., Ali, Z., \& Ali, M. (2021). An investigation on fresh and hardened properties of concrete blended with rice husk ash as cementitious ingredient and coal bottom ash as sand replacement material. Silicon, 1-12, DOI: 10.1007/ s12633-020-00906-3

7. Bheel, N., Jokhio, M. A., Abbasi, J. A., Lashari, H. B., Qureshi, M. I., \& Qureshi, A. S. (2020). Rice husk ash and fly ash effects on the mechanical properties of concrete. Engineering, Technology \& Applied Science Research, vol. 10 , no. 2, 5402-5405, DOI: 10.48084/etasr.3363.

8. Iraqi Standard Specification No-5 (2019). Portland cement, Central Agency for Standardization and Quality Control. Baghdad.

9. Iraqi Standard Specification No-45 (1984) Natural Aggregate Resources used in Concrete and Construction, Central Agency for Standardization and Quality Control. Baghdad.

10. Abbas, M. N., \& Abbas, F. S. (2013). Iraqi Rice Husk potency to eliminate toxic metals from aqueous solutions and utilization from process residues. Advances in Environmental Biology, 7(2), 308-319.

11. BS 1881: Part 113: 2011, Method for making and curing No-fines test cubes.

12. ASTM C496 / C496M-17 (2017). Standard Test Method for Splitting Tensile Strength of Cylindrical Concrete Specimens, ASTM International, West Conshohocken, PA, www.astm.org.
13. BS EN 12350-2:2019, (2019). Testing fresh concrete. Slump test.

14. BS EN 12390-3:2019, (2019). Testing hardened concrete. Compressive strength of test specimens.

15. ASTM C138 / C138M-17a (2017). Standard Test Method for Density (Unit Weight), Yield, and Air Content (Gravimetric) of Concrete, ASTM International, West Conshohocken, PA, www.astm.org.

16. ASTM C567 / C567M-19 (2019(. Standard Test Method for Determining Density of Structural Lightweight Concrete, ASTM International, West Conshohocken, PA, www.astm.org.

17. ASTM C293 / C293M-16, (2016). Standard Test Method for Flexural Strength of Concrete (Using Simple Beam With Center-Point Loading), ASTM International, West Conshohocken, PA, www.astm. org.

18. Bheel, N., Meghwar, S. L., Abbasi, S. A., Marwari, L. C., Mugeri, J. A., \& Abbasi, R. A. (2018). Effect of rice husk ash and water-cement ratio on strength of concrete. Civil Engineering Journal, vol. 4, no. 10, 2373-2382, DOI: 10.28991/cej-03091166.

19. Geiker, M., Thaulow, N., \& Andersen, P. J. (1991). Assessment of rapid chloride permeability test of concrete with and without mineral admixtures. durability of building materials and components. proceedings of the fifth international conference held in brighton, november 7-9, 1990. publication of: e and f spon limited.
Paper submitted: 09.06.2021.

Paper accepted: 21.07.2021.

This is an open access article distributed under the CC BY 4.0 terms and conditions. 